\title{
Etiopathogenesis and Diagnostic Strategies in Autoimmune Hepatitis
}

\author{
Weronika Domerecka ${ }^{1, *}$, Anna Kowalska-Kępczyńska ${ }^{2}$, Agata Michalak ${ }^{3}$, Iwona Homa-Mlak ${ }^{1}$, \\ Radosław Mlak ${ }^{1}{ }^{(1)}$, Halina Cichoż-Lach ${ }^{3}$ and Teresa Małecka-Massalska ${ }^{1}$ \\ 1 Chair and Department of Human Physiology, Medical University of Lublin, 20-080 Lublin, Poland; \\ iwona.homa@wp.pl (I.H.-M.); radoslaw.mlak@gmail.com (R.M.); \\ teresamaleckamassalska@umlub.pl (T.M.-M.) \\ 2 Department of Biochemical Diagnostics, Chair of Laboratory Diagnostics, Medical University of Lublin, \\ 20-081 Lublin, Poland; anna.kowalska-kepczynska@umlub.pl \\ 3 Department of Gastroenterology with Endoscopy Unit, Medical University of Lublin, 20-090 Lublin, Poland; \\ lady.agatamichalak@gmail.com (A.M.); halina.lach@umlub.pl (H.C.-L.) \\ * Correspondence: domereckaweronika@gmail.com
}

check for updates

Citation: Domerecka, W.; Kowalska-Kępczyńska, A.; Michalak, A.; Homa-Mlak, I.; Mlak, R.; Cichoż-Lach, H.; Małecka-Massalska, T. Etiopathogenesis and Diagnostic Strategies in Autoimmune Hepatitis. Diagnostics 2021, 11, 1418. https:// doi.org/10.3390/diagnostics11081418

Academic Editor: Roxana Sirli

Received: 26 May 2021

Accepted: 3 August 2021

Published: 5 August 2021

Publisher's Note: MDPI stays neutral with regard to jurisdictional claims in published maps and institutional affiliations.

Copyright: (C) 2021 by the authors. Licensee MDPI, Basel, Switzerland. This article is an open access article distributed under the terms and conditions of the Creative Commons Attribution (CC BY) license (https:// creativecommons.org/licenses/by/ $4.0 /)$.

\begin{abstract}
Autoimmune hepatitis (AIH) is a chronic liver disease with the incidence of 10 to 17 per 100,000 people in Europe. It affects people of any age, but most often occurs in the 40-60 age group. The clinical picture is varied, from asymptomatic to severe acute hepatitis or liver failure. The disease onset is probably associated with the impaired function of $\mathrm{T}$ lymphocytes, the development of molecular mimicry, intestinal dysbiosis, or infiltration with low density neutrophils, which, alongside autoantibodies (i.e., ANA, ASMA), implicate the formation of neutrophil extracellular traps (NETs), as a component of the disease process, and mediate the inappropriate immune response. $\mathrm{AIH}$ is characterized with an increased activity of aminotransferases, elevated concentration of serum immunoglobulin $\mathrm{G}$, the presence of circulating autoantibodies and liver inflammation. The result of the histological examination of the liver and the presence of autoantibodies, although not pathognomonic, still remain a distinguishing feature. The diagnosis of AIH determines lifelong treatment in most patients. The treatment is implemented to prevent the development of cirrhosis and end-stage liver failure. This work focuses mainly on the etiopathogenesis and diagnosis of AIH.
\end{abstract}

Keywords: autoimmune hepatitis; autoantibodies; LDG; NETs

\section{Introduction}

Autoimmune hepatitis $(\mathrm{AIH})$ is a complex immune disease of the liver $[1,2]$. It was first described in 1951 [3] as chronic hepatitis, occurring in young women with hypergammaglobulinemia, without cirrhosis, and responding well to adrenocorticotropic (ACTH) therapy [4].

AIH may be asymptomatic or manifest itself in various forms, ranging from subclinical disease to acute and end-stage liver failure [5]. Specific diagnostic criteria and classification systems have been established, including the presence of anti-nuclear antibodies (ANA), anti-smooth muscle antibodies (SMA), liver/kidney microsome type 1 antibodies (anti-LKM1), and anti-soluble liver antigen/liver pancreas (anti-SLA), immunoglobulin G (IgG), exclusion of viral markers (IgM antibody to hepatitis A virus (IgM anti-HAV), hepatitis B surface antigen (HBsAg), hepatitis B virus DNA (HBV DNA) and hepatitis C virus RNA (HCV RNA)) as well as the histological picture of the liver tissue [6]. According to the antibody profile, AIH can be divided into several subtypes: type 1, type 2, type 3 AIH and cryptogenic hepatitis [7]. The mainstays of AIH therapy are corticosteroids and immunosuppression. There are also therapeutic methods involving biological drugs [8], as well as cellular therapies [9]. Hepatic transplantation is a life-saving procedure in patients with acute liver failure caused by acute form of $\mathrm{AIH}$, or in patients with chronic liver failure and 
in the case of hepatocellular carcinoma. Disease recurrence after hepatic transplantation is reported in 10-50\% of patients, and the onset of de novo AIH has been described in both pediatric and adult liver transplant recipients [10].

\section{Epidemiology and Classification}

The incidence and characteristics of AIH differ in various geographic regions. AIH is a chronic disease with the incidence of 10 to 17 per 100,000 people in Europe, 17 cases per 100,000 in Norway and 31 cases per 100,000 in the US. The disease is considerably less frequent in Japan. A trend towards increased prevalence has been observed all over the world [11-13]. AIH was originally described in adolescent women. It is now known that it can occur in both genders, although it is more prevalent in women of all ages (70-80\% of cases) all over the world and in all ethnic groups [7,14]. AIH is a multi-organ disease. AIH may coexist with other autoimmune diseases. They include hypothyroidism, ulcerative colitis, type 1 diabetes mellitus, rheumatoid arthritis, coeliac disease $[7,14]$.

Epidemiological data show that $40-50 \%$ of cases are characterized by an acute onset of the disease, mainly in children [15], while $25 \%$ of patients already present with cirrhosis at the time of diagnosis. This indicates a long asymptomatic course of the disease leading to chronic or acute liver failure [16]. The course of AIH is, therefore, not always benign. Patients presenting with untreated severe disease are at high risk of death: $40 \%$ die within 6 months of diagnosis [12].

Currently, four types of AIH are distinguished. Type 1 AIH-more common in adults (45-70 years old), although it may also occur in younger people (10-20 years old). It is characterized by a mild course, the presence of antibodies (ANA and/or ASMA), predominantly against F-actin, and hypergammaglobulinemia. Type $2 \mathrm{AIH}$ is characteristic for children and young adults (however, it is the most prevalent in children aged 2-14 years). It has a rapid course with a frequent presence of anti-LKM antibodies, among which there are three types: anti-LKM1, anti-LKM2, anti-LKM3.

Out of the three types of these antibodies (anti-LKM1, anti-LKM2 and anti-LKM3), anti-LKM1 are the most typical for type $2 \mathrm{AIH}$. Their presence can also be observed in the case of HCV infection. Other antibodies that are often detected in type 2 AIH are anti-SLA/LP antibodies and LC-1 (anti-liver cytosol antibodies). The clinical course of type $3 \mathrm{AIH}$ is similar to type 1 . It is characterized by the presence of anti-SLA/LP antibodies. Adult women aged 30-50 years constitute 90\% of cases [17]. In addition, this type is associated with cryptogenic hepatitis with no antibodies found in the patient's serum. Table 1 shows the diversification of respective types of $\mathrm{AIH}$ according to the occurrence of particular autoantibodies [12,18].

Table 1. Autoimmune hepatitis (AIH) classification according to the presence of autoantibodies based on $[12,19,20]$.

\begin{tabular}{ccc}
\hline & \multicolumn{2}{c}{ AIH Types } \\
\hline \multirow{2}{*}{ Type } & Antibody & Prevalence \\
\hline \multirow{2}{*}{1} & ASMA & $40-90 \%$ \\
\cline { 2 - 3 } & ANA & $5-70 \%$ \\
\cline { 2 - 3 } & Anti-SLA/LP & $10-30 \%$ \\
\hline 3 & Anti-LKM-1 & $2-4 \%$ \\
\hline Cryptogenic hepatitis & Anti-LC1 & $1-2 \%$ \\
\hline
\end{tabular}

Anti-smooth muscle antibodies (ASMA), anti-nuclear antibodies (ANA), liver/kidney microsome antibodies (anti-LKM), anti-soluble liver antigen/liver pancreas antibodies (anti-SLA/LP), anti-liver cytosol antibodies (anti-LC1). 


\section{Etiology}

AIH etiology is not fully understood. The most important role may be attributed to genetic, environmental, toxic and infective factors, including hepatitis A virus (HAV) [21,22], hepatitis C virus (HCV) [23,24], hepatitis E virus (HEV) [25], measles morbillivirus [26], Epstein-Barr virus (EBV) [16] and herpes simplex virus (HSV) [27] as well as medicines [28,29]. It has been proven that drug metabolites may stimulate the production of antibodies against liver cells. Thus, the stimulation of the immune system may occur years before the occurrence of the first disease symptoms [30]. It is thought that the immune response directed towards hepatic autoantigens initiates and perpetuates liver damage. It has been demonstrated that there is an association between AIH etiology and changes within the human leukocyte antigen region (HLA) as well as major histocompatibility complex (MHC), located on the short arm of chromosome 6, which is involved in the presentation of antigen peptides to $\mathrm{T}$ lymphocytes and in the initiation of adaptive immune response [31,32] (Figure 1). The Genome of the Netherlands Project [33] indicated HLA-DRB1 * 0301 and DRB1* 0401 as genotypes associated with the susceptibility to AIH, while SH2B3 and CARD10 (genes in a region other than $H L A$ ) turned out to be significantly associated with AIH. A study by Cheh et al. [34] also suggests that allele (HLA)-DRB1 * 16:02) is associated with the pathomechanism of many autoimmune diseases such as systemic lupus erythematosus, anti-N-methyl-d-aspartate receptor (NMDAR) encephalitis, Graves' disease, myasthenia gravis, neuromyelitis optica and antibody-associated systemic vasculitis with microscopic polyangiitis (AASV-MPA) however, it is not associated with type $1 \mathrm{AIH}$, multiple sclerosis or rheumatoid arthritis.

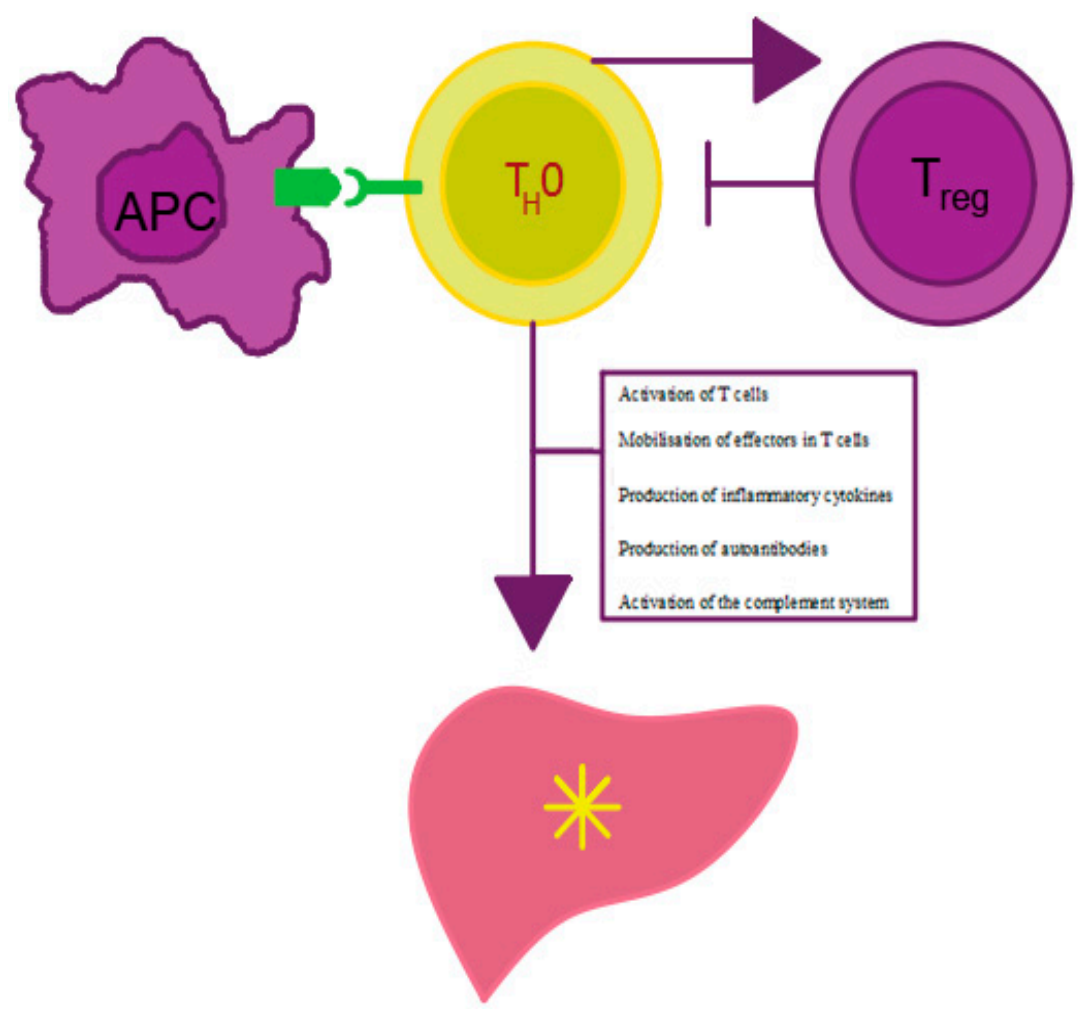

Figure 1. Mechanism of AIH development. APC — antigen presenting cell, Treg—regulatory T cell, Th0-T helper cell. Own elaboration based on [16]. Antigen presentation by APC cells to Th0 lymphocytes leads to effector mobilization on Treg cells and proinflammatory cytokine production. The cytokines stimulate antibody maturation and production by B lymphocytes and inhibit Treg lymphocyte activity. The decrease in the number of Treg lymphocytes leads to the impairment of tolerance to autoantigens, which, in turn, results in the initiation and persistence of autoimmune liver damage. 


\subsection{Molecular Mimicry and Intestinal Dysbiosis in Autoimmune Hepatitis (AIH)}

Molecular mimicry is one of the potential mechanisms leading to AIH in patients with increased genetic susceptibility. It works by inducing an immune response to exogenous pathogens that stems the production of antibodies that cross-react with liver autoantigens. This is due to their structural similarity to the antigens of pathogenic microorganisms of a similar structure [18,35-38]. Molecular mimicry is, therefore, based on the structural and sometimes also functional similarity between antigens of a microorganism and human antigens. An example of such a phenomenon in AIH is the homology of the biochemical structure of HCV, CMV (Cytomegalovirus) and HSV-1 viruses and the cytochrome P450 IID6 [39-42]. It has been shown that this antigen, as well as the short linear amino acid sequences of the CYP IA2 and CYP IIC11 proteins present in liver microsomes, can be recognized as microbial antigens by the serum antibodies present in $\mathrm{AIH}$ patients. The key role is attributed to the CYP IID6 molecule being the main antigen of anti-LKM-1 autoantibodies, which are characteristic for type 2 AIH [43].

Molecular mimicry is also recognized as a possible key element of microbiome-related autoimmunity. The gastrointestinal microflora plays an important role in shaping the intestinal and systemic immune response [44-49]. Its composition depends on gender, ethnicity, age, diet, and socioeconomic status [50-53]. Bacterial components of the intestinal microbiome can activate Toll-like receptors (TLRs) [51], contributing to the formation of inflammasomes, i.e., multiparticulate protein complexes that mediate the inflammatory response [54-57], stimulate the systemic immune response [58,59] and activate the intestinal immune cells that migrate to the peripheral lymphoid tissue [60,61]. Changes in the microbial composition of the intestine (dysbiosis) have already been associated with many diseases, such as type 1 diabetes [62], multiple sclerosis [63], inflammatory bowel disease [64,65], NAFLD (non-alcoholic fatty liver disease) [56], PBC (primary biliary cholangitis) [66,67], PSC (primary sclerosing cholangitis) [67,68] and AIH [68,69].

Patients with AIH demonstrate deficiencies in the zonula occludens 1 (ZO-1) and occludin structural proteins, which maintain the integrity of the mucosal barrier of the gastrointestinal tract [70]. In addition, they also show increased plasma levels of gut derived lipopolysaccharides (LPS) and a reduced amount of anaerobic bacteria [70,71]. Changes in the microbiome composition can lead to increased intestinal permeability, which in turn facilitates the passage of bacteria into the portal circulation [72-74]. Changes in the intestinal microflora have recently been described based on studies using an experimental humanized mouse model of AIH [69]. Also, a study by Wei et al. demonstrated changes in the composition and function of the intestinal microbiome in patients with $\mathrm{AIH}$, which indicates the possibility of using the composition of the intestinal microbiota as a noninvasive biomarker for the assessment of disease activity [75].

\subsection{Low-Density Granulocytes (LDG) and Neutrophil Extracellular Traps (NETs) in AIH}

There is ample evidence for the role of neutrophils and their distinct LDG (low-density granulocytes) subset in the development of AIH [76]. LDGs are neutrophils which, after separation using density gradient centrifugation, remain in the peripheral blood mononuclear cell (PBMC) fraction [77]. When they were first described, it was noted that they may be present in many rheumatic diseases, such as systemic lupus erythematosus (SLE) [78] and rheumatoid arthritis (RA) [79]. More recent studies also describe LDG in diseases such as asthma [80], tuberculosis [81], psoriasis [82], animal models of viral infection [83,84], arthritis [85], in people with cancer [86], sepsis [87], HIV [88,89], and various autoimmune diseases including AIH [76].

Similarly, to normal-density granulocytes (NDG), LDG neutrophils strongly express LDG-specific surface markers (CD10, CD15 and CD16), but, in contrast to NDG, their nucleus is immature [90,91]. LDGs exhibit features of reactive cells. When activated, they can damage endothelial cells and release large amounts of tumor necrosis factors (TNF) and type I and II interferons (IFNs) $[90,92,93]$. Activated by pathogenic microorganisms or pro-inflammatory cytokines, LDGs can undergo spontaneous death (i.e., the release of neu- 
trophil extracellular traps (NETs), which is also known as NETosis). NETs are composed of DNA, granules (including proteolytic enzymes) and the contents of the cell nucleus, which are released into the extracellular space [94,95]. Trapped in the chromatin NETs, pathogens are exposed to various substances, incl. cationic serine protease (proteinase 3, cathepsin $G$, neutrophil elastase (NE)), myeloperoxidase (MPO), bactericidal/permeability-increasing protein (BPI protein) with bactericidal permeability enhancing properties, lactoferrin, gelatin B, cathelicidin (LL-37 or cathelicidin antimicrobial peptide CAP-18) as well as histone proteins (core histones and linker histones H1) and tryptase [96].

The released substances destroy pathogenic microorganisms, contributing to inflammation and tissue damage $[97,98]$.

The involvement of NETs in AIH as a trigger mechanism has not yet been studied in detail. Probably the LDG infiltration, which is observed at the early stage of AIH, alongside the dominant autoantibodies, i.e., ANA or ASMA, implies the formation of NETs as a component of the disease process and influences an abnormal immune response. These studies suggest that the imbalance between the NET formation process and their degradation may be related to the development of autoimmune diseases. Neutrophils, interleukin-8, ANCA (anti-neutrophil cytoplasmic antibodies), and other inflammatory molecules are believed to play a key role in inducing NETs. Long-term exposure of organs to NETs is associated with the intensification of the autoimmune process and thus a greater risk of their damage [98].

However, both the level and the clinical significance of LDG associated with AIH are not yet understood. Nevertheless, growing evidence indicates that uncontrolled or excess production of NETs is associated with exacerbation of inflammation and the development of autoimmunity in AIH. Nevertheless, research related to NETs may be helpful in elucidating the mechanism of AIH development and in the elaboration of novel diagnostic and therapeutic strategies.

\section{Clinical Symptoms and Diagnostics of AIH}

AIH is asymptomatic for a long time. The most common clinical symptoms of advanced forms of AIH include ascites (91\% of patients), progressive jaundice (69-88\% of patients), anorexia, asymptomatic hepatosplenomegaly (50\% of patients) and abdominal pain (over $50 \%$ of patients). $20 \%$ of patients with AIH develop epistaxis, acne, fever and tender hepatomegaly, which often is the only clinical symptom. Regardless of the stage of the disease (exacerbation or remission), patients often complain of bothersome weariness and fatigue. The presence of these symptoms should be taken into account when diagnosing chronic fatigue syndrome.

The diagnosis of AIH is difficult, even in the case of an acute relapse [99]; the laboratory markers do not always facilitate a clear diagnosis. Moreover, diagnostic difficulties often concern a group of patients with features of already developed chronic liver damage due to AIH. In such case, a detailed differential diagnosis should be carried out in order to establish the pathogenesis of these disorders. It is essential to eliminate the potential toxic damage to hepatocytes (mainly alcohol abuse) and the possible infection with hepatotropic viruses (e.g., HBV, HCV, CMV) as well as biliary pathology. Thereafter, it is justified to start the diagnostics towards autoimmune liver diseases. In clinical practice, the following three most common disease entities are usually considered: AIH, PBC and PSC. The clinical picture of AIH commonly differs from PBC and PSC, nevertheless, the above diseases may occur concomitantly, which may also constitute a real diagnostic challenge in some cases. However, AIH usually manifests itself insidiously, beginning with intensifying symptoms of chronic liver disease, and patients can sometimes be diagnosed after accidental detection of abnormal liver function tests [100]. Moreover, other autoimmune diseases such as PBC and PSC [101], as well as systemic sclerosis [102] are also encountered in patients with AIH.

There is no single test that allows definitive diagnosis of AIH. The diagnosis is based solely on a combination of clinical, serological, biochemical, and histological findings. One of the most important diagnostic criteria for autoimmune hepatitis is the presence of 
serum autoantibodies, which can be detected by such methods as: indirect immunofluorescence technique (IIFT) [103], enzyme-linked immunosorbent assay (ELISA) [104] or immunoblotting [105] (Figure 2). Laboratory tests demonstrate hypergammaglobulinemia and a selective increase in IgG, sometimes a slight increase in IgM, elevated transaminase activity, especially of alanine aminotransferase (ALT) and aspartate aminotransferase (AST), usually 5-fold above normal values. Sometimes, in advanced stages of the disease, increased bilirubin and hypoalbuminemia are observed. The levels of cholestasis markers—alkaline phosphatase (ALP) and gamma-glutamyltransferase (GGTP) — are usually normal or slightly elevated. Other causes of hepatitis should be carefully ruled out, especially alcohol, drugs or viruses.
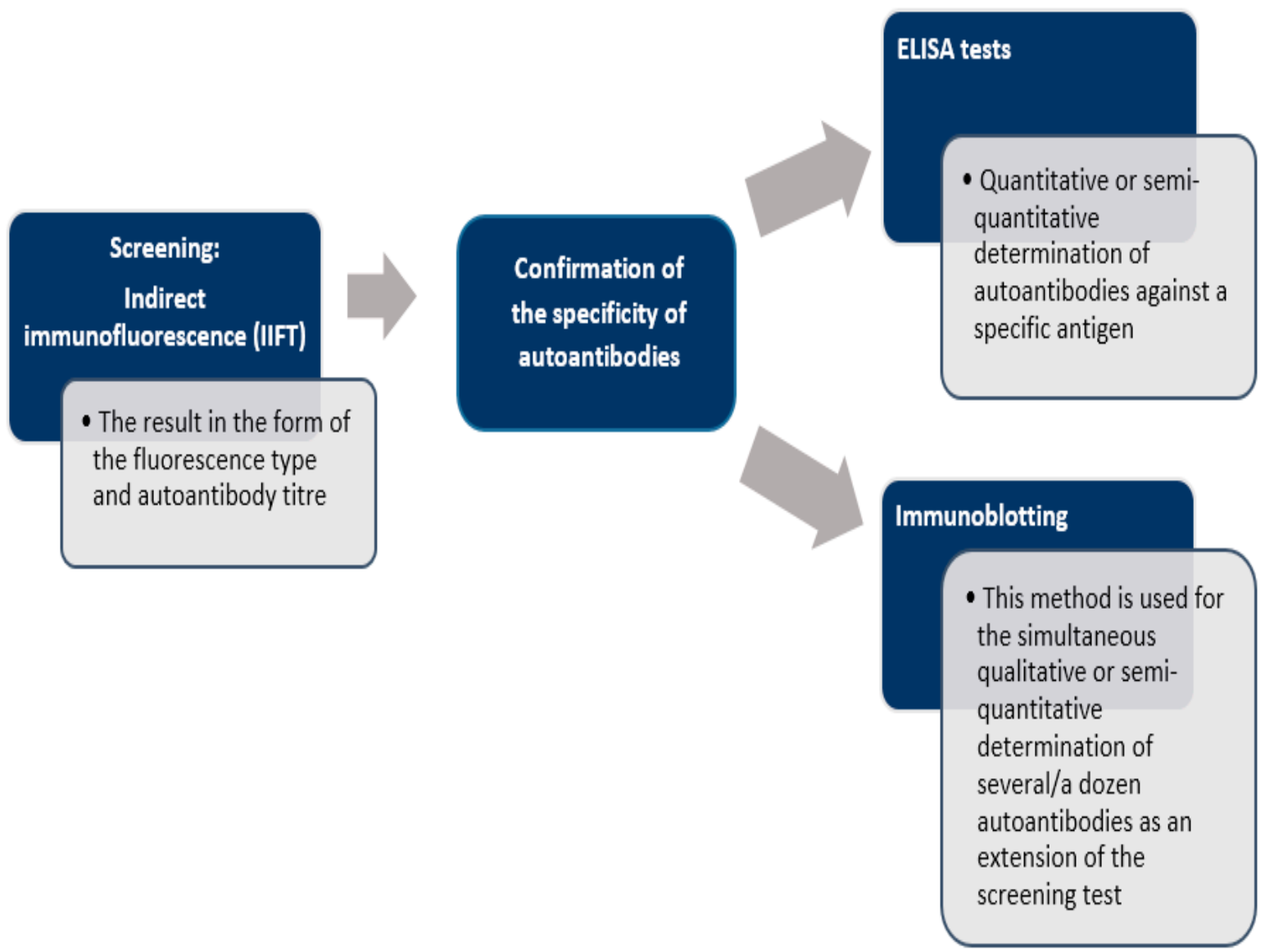

Figure 2. Scheme of laboratory diagnosis of autoimmune liver disease [19,105].

\section{Autoantibodies}

The main autoantibodies in AIH include: ASMA, ANA, anti-SLA/LP, anti-LKM and anti-LC1. The first diagnostic criteria were established in 1992 by the Autoimmune Hepatitis Group [106]. They were then revised in 1999 [107]. However, the revised criteria included complex and insufficiently validated parameters of questionable value, which were mainly developed to allow comparisons of studies from different centers. Consequently, simplified criteria were proposed that included 4 instead of 12 diagnostic parameters to facilitate wider application in routine clinical practice. These criteria, constituting the basis for result calculation, include the quantification of autoantibodies (ANA, anti-SMA, anti-LKM-1 antibody titers), immunoglobulin G, and the assessment of liver histology (evidence of hepatitis, lymphoplasmatic infiltration) [7]. The potential diagnosis is considered when the score equals 6 . The score equal to or greater than 7 indicated definitive diagnosis of AIH. The simplified criteria are presented in Table 2 [6,7,108,109]. 
Table 2. Simplified criteria for AIH diagnostics of the International Autoimmune Hepatitis Group (IAHG) $[7,12,18]$.

\begin{tabular}{ccc}
\hline Parameter & Value & Score \\
\hline \multirow{2}{*}{ ANA or ASMA } & $>1: 40$ & 1 \\
& $>1: 80$ & 2 \\
\hline or LKM & $>1: 40$ & 2 \\
\hline or SLA & Present & 2 \\
\hline \multirow{2}{*}{ IgG } & $>$ ULN & 1 \\
& Over 10\% above ULN & 2 \\
\hline \multirow{2}{*}{ Histopathologic examination } & Corresponding to AIH & 1 \\
& Typical for AIH & 2 \\
\hline Hepatotropic viruses & Negative test result & 2 \\
\hline ANA—anti-nuclear antibodies; & ASMA—anti-smooth muscle antibodies; SLA-anti-soluble liver antigen; \\
LKM—anti-liver/kidney microsome antibodies; IgG-immunoglobulin G; ULN—upper limit of normal.
\end{tabular}

The measurement of autoantibodies, which has been included in all scoring systems, is a key step in both the diagnosis and classification of $\mathrm{AIH}$, and should be performed in all patients suspected of this disease [110].

ASMA, or anti-SMA. They react with the antigens of the muscle structures: F-actin and non-active components of the cellular cytoplasm. Their high and persistent titer $(>1: 1000)$ is one of the criteria for the diagnosis of AIH-1. They occur in $87 \%(40-90 \%)$ of patients with AIH-1 (in 33\% as the only ones, in 54\% in combination with ANA). It should be kept in mind that low ASMA titers are found in viral drug-induced hepatitis, alcoholic cirrhosis, biliary obstruction and visceral lupus [19].

Anti-SLA/LP antibodies are a highly specific marker of autoimmune hepatitis and indicate a severe course of the disease. The diagnostic value of anti-SLA/LP is close to $100 \%$-any positive result is very likely to indicate type $1 \mathrm{AIH}$, provided that the appropriate clinical symptoms are present. Unlike other autoantibodies, anti-SLA/LP antibodies are highly specific for AIH and have not been reported in other diseases. Anti-SLA/LP can be present in type $1 \mathrm{AIH}$ together with other autoantibodies or as a sole marker [111].

Anti-LKM-1 antibodies can occur in both type $2 \mathrm{AIH}$ and HCV infections. The prevalence of $\mathrm{AIH}$ in adults is about $1 \%$, being more common in children. Other types of anti-LKM antibody are not associated with autoimmune liver diseases, anti-LKM-2 are present in patients with drug-induced lesions, and anti-LKM-3 are present in $10-15 \%$ of patients with HBV/HDV [111].

Anti-LC1 antibodies are associated with a more severe form of the disease-type 2 $\mathrm{AIH}$. The prevalence of anti-LC1 antibodies is $1-2 \%$; they are more common in patients with anti-LKM-1 without HCV infection. They are the only indicator of the disease in $14 \%$ of patients. They can be detected by indirect immunofluorescence method, however, due to the frequent simultaneous presence of anti-LKM-1 autoantibodies, which react in the same areas of the liver tissue, they can easily get overlooked. For this reason, it is recommended to perform a monospecific test. ELISA or immunoblotting are used to confirm their presence. The target antigen for anti-LC1 antibodies is formimidoyltransferase cyclodeaminase (FTCD) and this recombinant protein is the antigen used in the ELISA and immunoblotting methods [112].

\subsection{Histological Findings in Liver Biopsy Specimens Obtained from AIH Patients}

According to the American Association for the Study of Liver Diseases (AASLD) [113] and European Association for the Study of the Liver (EASL) [114] guidelines, liver biopsy still remains a recommended gold standard in the diagnosis of AIH and in the evaluation of liver fibrosis stage during the disease. Moreover, histological demonstration of hepatitis constitutes a core component of commonly used diagnostic scores in AIH. Simultaneously, liver biopsy makes it possible to exclude other potential causative factors of existing liver 
disorder and finally to establish the further management of $\mathrm{AIH}$ patients. It is also the only way to confirm the presence of the disease in case of the lack of serological antibodies (up to $20 \%$ cases of $\mathrm{AIH}$ ) [115]. The key histological disturbance in the pathological appearance of AIH is reflected by chronic active hepatitis, which includes marked portal inflammation, interface hepatitis and lobular hepatitis with varying severity [16]. The character of histological findings depends on the stage of disease; however, a hepatic pattern of injury is typical $[116,117]$. Hepatocellular damage together with parenchymal necrosis or apoptosis are distinctive for lobular hepatitis and might be found within lobular zones and periportal areas. Furthermore, damaged limiting plates form an interface between lobular hepatitis and portal hepatitis. A migration of lymphocytes and plasma cells from the portal tract into the area of periportal parenchyma occurs and this forms interface hepatitis (piecemeal necrosis)-a typical hallmark of chronic active hepatitis regardless of its etiology and directly linked to the disease progression. Thus, an active phase of AIH is reflected by the presence of interface hepatitis. The spectrum of lobular hepatitis includes single cell necrosis, spotty necrosis, focal necrosis, confluent necrosis (bridging/zonal necrosis) and submassive/massive necrotic lesions with reference to the degree of hepatocellular damage and location of affected lobules. Emperipolesis (the phenomenon of engulfment of lymphocytes by hepatocytes) might be observed in zones of interface activity even in approximately $70 \%$ of $\mathrm{AIH}$ cases. However, emperipolesis does not belong to pathognomonic characteristics of AIH and is also described in patients with PBC, DILI (drug-induced liver injury) or chronic viral hepatitis. The engulfed cells are mainly represented by CD8+ T cells and CD56+ NK cells (ang. natural killer T) and rarely plasma cells. In the majority of cases, the presence of emperipolesis in $\mathrm{AIH}$ is accompanied by coexisting high activity of transaminases in serum and necroinflammatory lesions in liver parenchyma including confluent necrosis of centrilobular area (centrilobular necrosis) [118,119]. Additionally, the presence of hepatocyte rosette-like formation due to the thickening of liver cell plates during regeneration is also common in AIH. Prominent plasma cells are often in the portal inflammatory infiltrate, nevertheless one-third of biopsies obtained from AIH patients will contain few or no plasma cells. Of note, severe portal inflammation associated with AIH might be accompanied by bile ducts damage (typical in the course of PBC or PSC). Moreover, perivenular necroinflammatory activity, characterized by prominent mononuclear inflammation and hepatocellular necrosis surrounding terminal hepatic venules, can be found especially in the early phase of AIH. Simultaneously, the regeneration of hepatocytes occurs closely to necrotic regions. These regenerating cells organize into clusters of small monomorphic hepatocytes with clear cytoplasm giving a "cobblestone" appearance in biopsy specimens from AIH patients. In this cobblestone space, the trabeculae of hepatocytes tend to be thick and hepatic rosette formation is often seen as the consequence of central lumen formation. The fibrosis stage at the time of diagnosis varies from no fibrotic changes, through minimal fibrosis and finally to established liver cirrhosis. The already developed cirrhotic stage of AIH might have no pathognomonic histopathological features (so-called burnt-out disease) and the diagnosis of existing AIH can be based only on clinical presentation and serologic data [120-122].

\subsection{AIH Treatment-Known Players and Future Perspectives}

A key goal in the treatment of already diagnosed AIH is to control hepatic inflammation to achieve clinical, biochemical and histopathological remission of the disease, (Figure 3). The most favorable profile of biochemical response to the treatment is the normalization of the serum AST, ALT, and IgG levels. Histopathological remission results from biochemical response. Of note, sustaining biochemical remission for a long time ( $>1$ year from the application of treatment) constitutes a surrogate for satisfying overall long-term survival [13]. The first-line paradigm is based on corticosteroids in monotherapy or in combination with azathioprine (AZA). The 2019 AASLD guidelines propose either prednisone monotherapy (40-60 mg/day) or a combination of prednisone (20-40 mg/day) or budesonide (9 mg/day) and AZA (50-100 mg/day) [113]. The 2015 
EASL guidelines recommend $0.5-1 \mathrm{mg} / \mathrm{kg} /$ day predniso(lo)ne as the initial treatment, followed by a $50 \mathrm{mg} /$ day AZA add-on [114]. The AASLD also suggests a period of a 2-week observation before the initiation of AZA in order to confirm the patient's steroid responsiveness and to evaluate the status of thiopurine-S methyltransferase (TPMT) to avoid AZA-induced hepatitis. TPMT metabolizes thiopurines (e.g., AZA) and single nucleotide polymorphisms of its genes can result in the loss of enzymatic activity. This disorder predisposes patients (especially European and African descendants) to the development of thiopurine-related toxicity [123]. To evaluate the relevance of the starting dose of predniso(lo)ne, a retrospective observational study was performed in nine sites located in five European countries. This demonstrated that an initial low dose of AZA in the majority of patients ( $>85 \%$ ) significantly decreased the unnecessary exposure to predniso(lo)ne in more than $85 \%$ of patients. Furthermore, budesonide has been proved to cause less systemic side effects, due to a $90 \%$ first-pass hepatic clearance rate [124]. The AASLD even demonstrated a higher rate of biochemical remission in the budesonide + AZA group compared to the prednisone + AZA group (odds ratio, 2.19; 95\% CI, 1.30-3.67). Thus, the AASLD suggests budesonide in combination with AZA as a first-line therapy for pediatric and adult AIH patients without cirrhosis or acute severe $\mathrm{AIH}$. Budesonide is contraindicated in cirrhotic patients because of portosystemic shunting which may reduce the drug's efficacy. The combination of AZA with either predniso(lo)ne or budesonide is now believed to be the most standard first-line therapy of AIH in western countries $[13,125]$. As corticosteroids are still the mainstay of the first-line treatment of $\mathrm{AIH}$, limiting corticosteroids-related osteoporosis in patients with risk factors is required during treatment to promote bone preservation [126]. In patients with refractoriness, incomplete biochemical response and intolerance to first-line treatment, mycophenolate mofetil (MMF), calcineurin inhibitors (cyclosporin A, tacrolimus), mercaptopurine, and biologics (e.g., infliximab) are taken into consideration. The combination of MMF and prednisone appears to be the most widely suggested second-line treatment, leading to histological remission in $89 \%$ of the patients [127]. Another survey confirmed the effectiveness of MMF as a second-line therapy for AIH patients who have failed standard therapy; the rate of induction of biochemical remission was $60 \%$ [128]. A significant number of AIH patients will have to face spontaneous and asymptomatic exacerbation or recrudescence, reflected by an increased level of ALT (with or without elevation in IgG). Multiple relapses are known to be surrogates of worse outcomes [129]. On the other hand, a sustained biochemical remission of $\geq 2$ years was suggested by the AASLD as the eligibility criterion for considering a treatment withdrawal. AIH with already decompensated cirrhosis in its course or acute liver failure requires liver transplantation (LT). According to the results of the prospective multicenter European Liver Transplant Registry (1998-2017), the general survival of patients after AIH-LT was reported to be comparable to that of patients after alcohol-related cirrhosis-LT, however, worse than in the case of primary biliary cholangitis-LT and primary sclerosing cholangitis-LT.69 The 5 - and 10-year patient survival rates in the AIH group were $79.4 \%$ and $73.25 \%$, respectively, with corresponding graft survival rates of $70.8 \%$ and $63.4 \%$ [130]. The future of the AIH treatment rests in the novel agents directly targeting the early stages of the inflammatory cascade responsible for the development of the disease. Anti-B cell-activating factor of the tumor necrosis factor family (BAFF) and anti-tumor necrosis factor (TNF) therapies, novel peptides, T regulatory cells, interleukin (IL)-1 or IL-6 blockade and Janus kinases are worth mentioning as potential players in this field. But there is still a great need for subsequent studies assessing their usefulness in AIH patients [131,132]. 


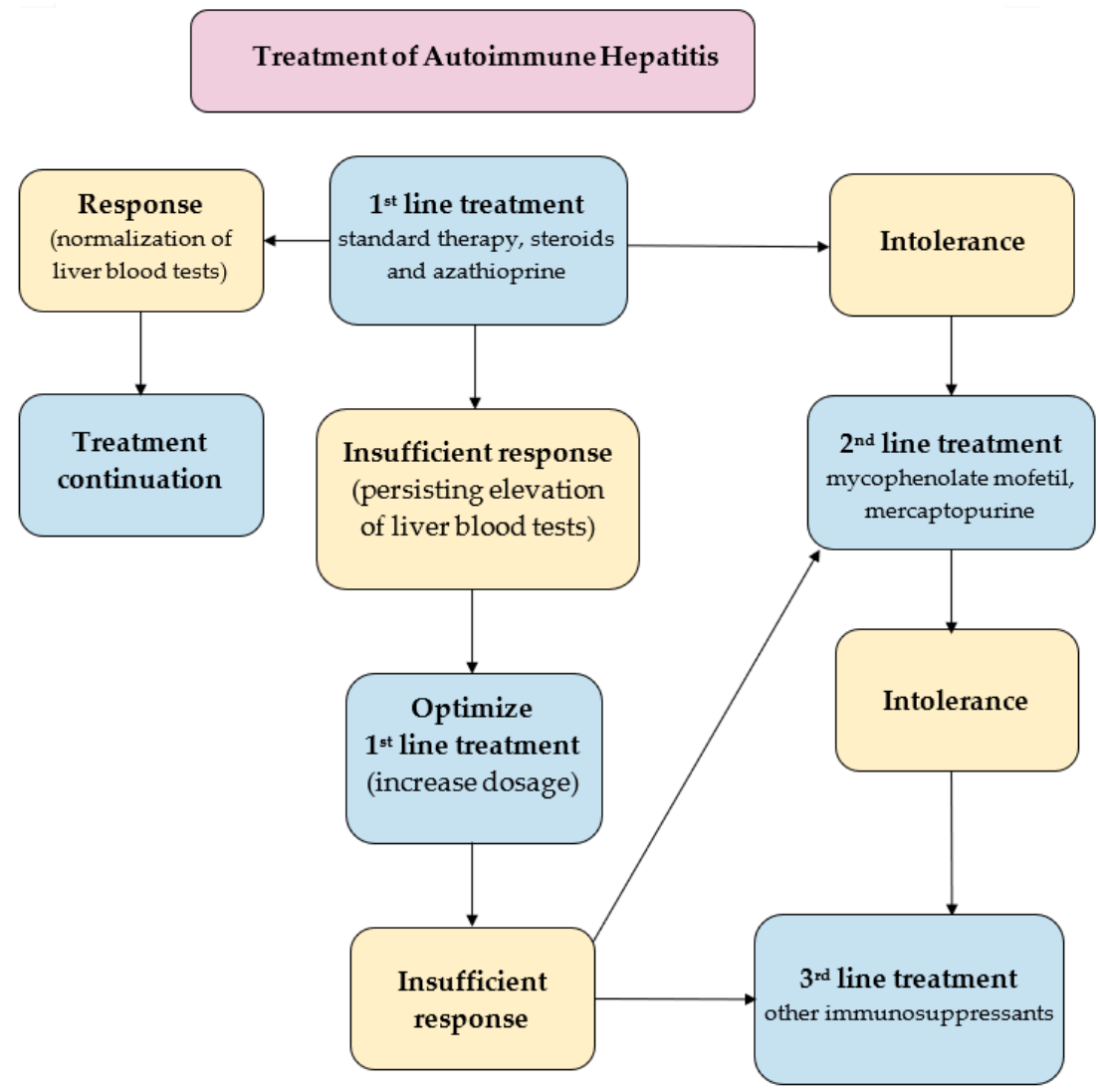

Figure 3. Treatment strategies in AIH [113,114,125,127].

\section{Summary}

In recent decades, significant progress has been made in understanding the pathogenesis and diagnosis of $\mathrm{AIH}$, but the exact cause of this disease's development is still unknown. Human genome studies have identified the key predisposing HLA allelic variants associated with the development of $\mathrm{AIH}$. In addition, an increasing number of studies are suggesting a significant role of NETs in exacerbating inflammation and the occurrence of autoimmune diseases, including $\mathrm{AIH}$.

The currently used diagnostic systems are characterized with high sensitivity and specificity, but there is still no test that would quickly and easily contribute to the detection of this disease. However, thanks to the advancement of science, it is possible to explore the most unconventional etiologies, such as NETs, and the intestinal microbiome as factors contributing to the development of the disease. In the future, this knowledge can contribute to the implementation of new therapies and innovative diagnostic methods.

Author Contributions: All the contributors to the paper fulfil the European Journal of Pathology Criteria for Authorship. Conceptualization, W.D. and A.K.-K.; methodology, W.D.; software, W.D.; validation, W.D., A.K.-K. and A.M.; formal analysis, W.D.; investigation, W.D.; resources, W.D.; data curation, W.D., A.K.-K. and A.M.; writing-original draft preparation, W.D., A.K.-K. and A.M.; writing-review and editing, R.M., T.M.-M. and H.C.-L.; visualization, W.D.; supervision, R.M. and I.H.-M.; project administration, T.M.-M. and H.C.-L.; funding acquisition, T.M.-M. All authors have read and agreed to the published version of the manuscript.

Funding: The authors did not receive support from any organization for the submitted work.

Institutional Review Board Statement: Not applicable.

Informed Consent Statement: Not applicable.

Data Availability Statement: Not applicable.

Conflicts of Interest: The authors have no relevant financial or non-financial interests to disclose. 


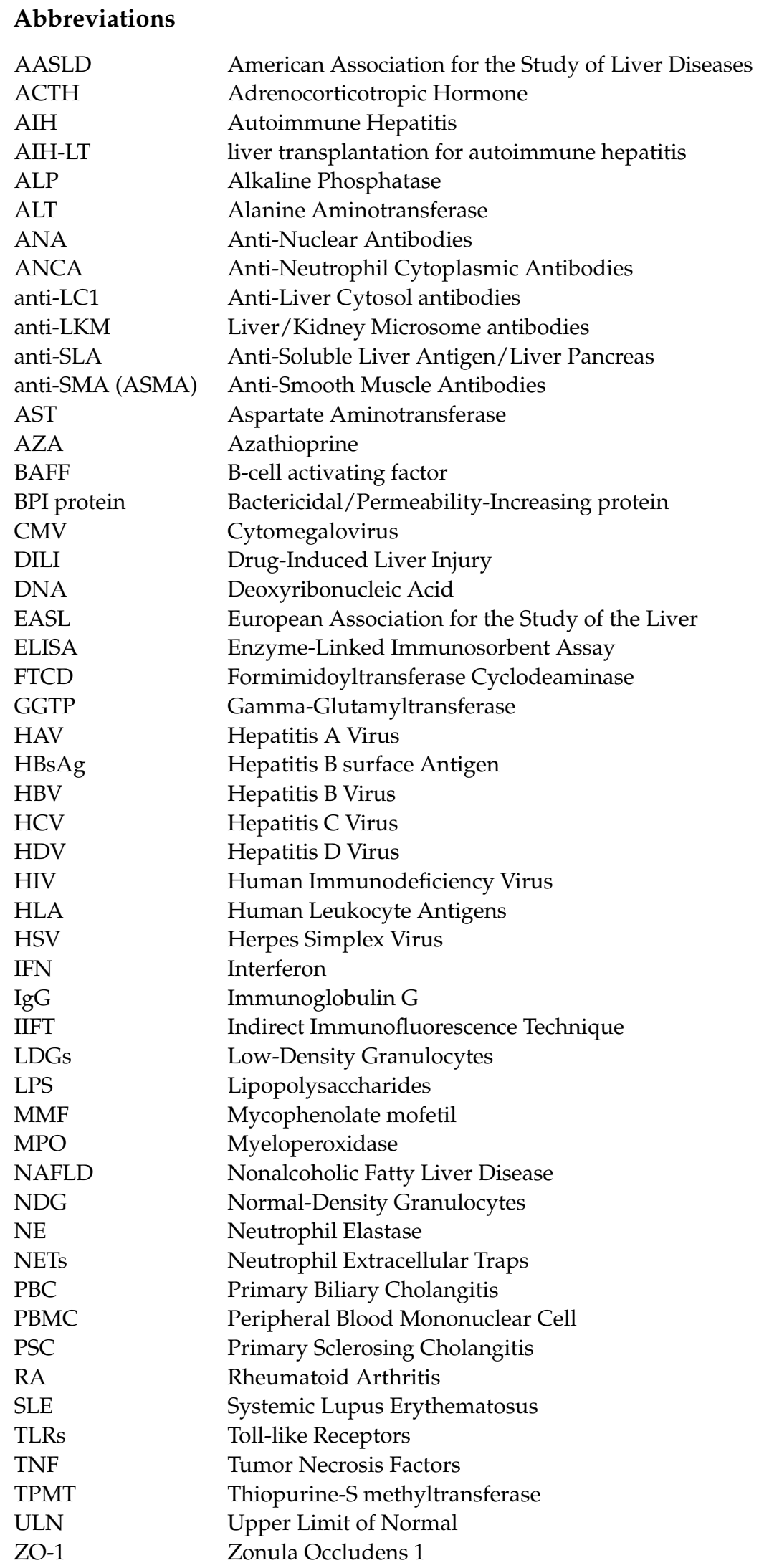

\section{References}

1. Floreani, A.; Restrepo-Jiménez, P.; Secchi, M.F.; De Martin, S.; Leung, P.S.C.; Krawitt, E.; Bowlus, C.L.; Gershwin, M.E.; Anaya, J.M. Etiopathogenesis of autoimmune hepatitis. J. Autoimmun. 2018, 95, 133-143. [CrossRef]

2. Tanaka, A. Autoimmune Hepatitis 2019 Update. Gut Liver 2020, 14, 430-438. [CrossRef] [PubMed] 
3. Waldenstrom, J. Liver, blood proteins and food proteins. Dtsch. Z. Verdau. Stoffwechselkr. 1952, 12, 113-121. [PubMed]

4. Pape, S.; Schramm, C.; Gevers, T.J. Clinical management of autoimmune hepatitis. United Eur. Gastroenterol. J. $2019,7,1156-1163$. [CrossRef] [PubMed]

5. Czaja, A.J. Diagnosis and management of autoimmune hepatitis: Current status and future directions. Gut Liver 2016, 10, 177-203. [CrossRef] [PubMed]

6. Habior, A.; Hartleb, M.; Milkiewicz, P.; Gutkowski, K.; Cichoż-Lach, H.; Mach, T.; Ciećko-Michalska, I.; Ferenc, M.; Tomasz Bobiński, T.; Raszeja-Wyszomirska, J.; et al. Rekomendacje Sekcji Hepatologicznej Polskiego Towarzystwa Gastroenterologii dotyczące cholestatycznych chorób watroby-Adaptacja wytycznych europejskich. Gastroenterol. Klin. 2013, $5,5-39$.

7. Hennes, E.M.; Zeniya, M.; Czaja, A.J.; Parés, A.; Dalekos, G.N.; Krawitt, E.L.; Bittencourt, P.L.; Porta, G.; Boberg, K.M.; Hofer, H.; et al. Simplified criteria for the diagnosis of autoimmune hepatitis. Hepatology 2008, 48, 169-176. [CrossRef]

8. Chang, C.; Tanaka, A.; Bowlus, C.; Gershwin, M.E. The use of biologics in the treatment of autoimmune liver disease. Expert Opin. Investig. Drugs 2020, 29, 385-398. [CrossRef]

9. Czaja, A.J. Drug choices in autoimmune hepatitis: Part B-Nonsteroids. Expert Rev. Gastroenterol. Hepatol. 2012, 6, 617-635. [CrossRef]

10. Mendes, F.; Couto, C.A.; Levy, C. Recurrent and de novo autoimmune liver diseases. Clin. Liver Dis. 2011, 15, 859-878. [CrossRef]

11. Boberg, K.M. Prevalence and epidemiology of autoimmune hepatitis. Clin. Liver Dis. 2002, 6, 635-647. [CrossRef]

12. Francque, S.; Vonghia, L.; Ramon, A.; Michielsen, P. Epidemiology and treatment of autoimmune hepatitis. Hepatic Med. 2012, 4, 1-10.

13. Komori, A. Recent updates on the management of autoimmune hepatitis. Clin. Mol. Hepatol. 2012, 27, 58-69. [CrossRef]

14. Heneghan, M.A.; Yeoman, A.D.; Verma, S.; Smith, A.D.; Longhi, M.S. Autoimmune hepatitis. Lancet 2013, 382, 1433-1444. [CrossRef]

15. Smolka, V.; Tkachyk, O.; Ehrmann, J.; Karaskova, E.; Zapalka, M.; Volejnikova, J. Acute onset of autoimmune hepatitis in children and adolescents. Hepatobiliary Pancreat. Dis. Int. 2020, 19, 17-21. [CrossRef]

16. Mieli-Vergani, G.; Vergani, D.; Czaja, A.J.; Manns, M.P.; Krawitt, E.L.; Vierling, J.M.; Lohse, A.W.; Montano-Loza, A.J. Autoimmune hepatitis. Nat. Rev. Dis. Primers 2018, 4, 18018. [CrossRef]

17. Than, N.N.; Jeffery, H.C.; Oo, Y.H. Autoimmune Hepatitis: Progress from Global Immunosuppression to Personalised Regulatory T Cell Therapy. Can. J. Gastroenterol. Hepatol. 2016, 2016, 7181685. [CrossRef] [PubMed]

18. Manns, M.P.; Michael, P.L.; Vergani, D. Autoimmune hepatitis-Update. J. Hepatol. 2015, 62, S100-S111. [CrossRef] [PubMed]

19. Klimczak-Filippowicz, M. Badania autoprzeciwciał w chorobach watroby. Diagn. Lab. 2020, 1, $23-24$.

20. Cancado, E.; Abrantes-Lemos, C.; Terrabuio, D. The importance of autoantibody detection in autoimmune hepatitis. Front. Immunol. 2015, 6, 222. [CrossRef] [PubMed]

21. Vento, S.; Garofano, T.; Di Perri, G.; Dolci, L.; Concia, E.; Bassetti, D. Identification of hepatitis A virus as a trigger for autoimmune chronic hepatitis type 1 in susceptible individuals. Lancet 1991, 337, 1183-1187. [CrossRef]

22. S-Are, V.; Yoder, L.; Samala, N.; Nephew, L.; Lammert, C.; Vuppalanchi, R. An Outbreak Presents An Opportunity to Learn About A Rare Phenotype: Autoimmune Hepatitis After Acute Hepatitis A. Ann. Hepatol. 2020, 19, 694-696. [CrossRef]

23. Vento, S.; Cainelli, F.; Renzini, C.; Concia, E. Autoimmune hepatitis type 2 induced by HCV and persisting after viral clearance. Lancet 1997, 350, 1298-1299. [CrossRef]

24. Cacciato, V.; Casagrande, E.; Bodini, G.; Furnari, M.; Marabotto, E.; Grillo, F.; Giannini, E.G. Eradication of hepatitis C virus infection disclosing a previously hidden, underlying autoimmune hepatitis: Autoimmune hepatitis and HCV. Ann. Hepatol. 2020, 19, 222-225. [CrossRef] [PubMed]

25. Le Cann, P.; Tong, M.J.; Werneke, J.; Coursaget, P. Detection of antibodies to hepatitis E virus in patients with autoimmune chronic active hepatitis and primary biliary cirrhosis. Scand. J. Gastroenterol. 1997, 32, 387-389. [CrossRef]

26. Vento, S.; Cainelli, F.; Ferraro, T.; Concia, E. Autoimmune hepatitis type 1 after measles. Am. J. Gastroenterol. 1996, 91, 2618-2620. [PubMed]

27. Manns, M.P. Viruses and autoimmune liver disease. Intervirology 1993, 35, 108-115. [CrossRef] [PubMed]

28. Droz, N.; Chevrier, F.; Lapointe, A.K. Autoimmune hepatitis as a sequelae of oxcarbazepine-induced drug reaction with eosinophilia and systemic symptoms. J. Allergy Clin. Immunol. Pract. 2021, 9, 580-581. [CrossRef] [PubMed]

29. Kawasaki, E.; Fukuyama, T.; Kuriyama, E.; Uchida, A.; Sagara, Y.; Tamai, H.; Nakano, Y.; Tojikubo, M.; Koga, N. Statin-induced autoimmune hepatitis in patients with type 1 diabetes: A report of two cases and literature review. J. Diabetes Investig. 2020, 11, 1673-1676. [CrossRef]

30. Czaja, A.J. Transitioning from idiopathic to explainable autoimmune hepatitis. Dig. Dis. 2015, 60, 2881-2900. [CrossRef]

31. Liberal, R.; Longhi, M.S.; Mieli-Vergani, G.; Vergani, D. Pathogenesis of autoim-mune hepatitis. Best Pract. Res. Clin. Gastroenterol. 2011, 25, 653-664. [CrossRef] [PubMed]

32. Lu, J.G.; Ji, P.; French, S.W. The Major Histocompatibility Complex Class II-CD4 Immunologic Synapse in Alcoholic Hepatitis and Autoimmune Liver Pathology: The Role of Aberrant Major Histocompatibility Complex Class II in Hepatocytes. Am. J. Pathol. 2020, 190, 25-32. [CrossRef]

33. de Boer, Y.S.; van Gerven, N.M.; Zwiers, A.; Verwer, B.J.; van Hoek, B.; van Erpecum, K.J.; Beuers, U.; van Buuren, H.R.; Drenth, J.P.; den Ouden, J.W.; et al. Genome-wide association study identifies variants associated with autoimmune hepatitis type 1. Gastroenterology 2014, 147, 443-452. [CrossRef] 
34. Chen, Y.; Li, S.; Huang, R.; Zhang, Z.; Petersen, F.; Zheng, J.; Yu, X. Comprehensive meta-analysis reveals an association of the HLA-DRB1*1602 allele with autoimmune diseases mediated predominantly by autoantibodies. Autoimmun. Rev. 2020, 19, 102532. [CrossRef]

35. Cusick, M.F.; Libbey, J.E.; Fujinami, R.S. Molecular mimicry as a mechanism of autoimmune disease. Clin. Rev. Allergy Immunol. 2012, 42, 102-111. [CrossRef] [PubMed]

36. Oldstone, M.B. Molecular mimicry: Its evolution from concept to mechanism as a cause of autoimmune diseases. Monoclon. Antib. Immunodiagn. Immunother. 2014, 33, 158-16547. [CrossRef]

37. Rose, N.R. Molecular mimicry and clonal deletion: A fresh look. J. Theor. Biol. 2015, 375, 71-76. [CrossRef]

38. Rojas, M.; Restrepo-Jiménez, P.; Monsalve, D.M.; Pacheco, Y.; Acosta-Ampudia, Y.; Ramírez-Santana, C.; Leung, P.S.C.; Ansari, A.A.; Gershwin, M.E.; Anaya, J.M. Molecular mimicry and autoimmunity. J. Autoimmun. 2018, 95, 100-123. [CrossRef]

39. Manns, M.P.; Griffin, K.J.; Sullivan, K.F.; Johnson, E.F.E. LKM-1 autoantibodies recognize a short linear sequence in P450IID6, a cytochrome P-450 monooxygenase. J. Clin. Investig. 1991, 88, 1370-1378. [CrossRef]

40. Ma, Y.; Thomas, M.G.; Okamoto, M.; Bogdanos, D.P.; Nagl, S.; Kerkar, N.; Lopes, K.N.; Luigi Muratori, L.; Marco Lenzi, M.; Francesco, B.; et al. Key residues of a major cytochrome P4502D6 epitope are located on the surface of the molecule. J. Immunol. 2002, 169, 277-285. [CrossRef] [PubMed]

41. Kerkar, N.; Choudhuri, K.; Ma, Y.; Mahmoud, A.; Bogdanos, D.P.; Muratori, L.; Bianchi, F.; Williams, R.; Mieli-Vergani, G.; Vergani, D. Cytochrome P4502D6(193-212): A new immunodominant epitope and target of virus/self cross-reactivity in liver kidney microsomal autoantibody type 1-positive liver disease. J. Immunol. 2003, 170, 1481-1489. [CrossRef]

42. Czaja, A.J. Examining pathogenic concepts of autoimmune hepatitis for cues to future investigations and interventions. World J. Gastroenterol. 2019, 25, 6579-6606. [CrossRef]

43. Prandota, J. Fundamentals of pharmacogenetics in autoimmune diseases in children. Stand. Med. 2003, 5, 1108-1114.

44. Macpherson, A.J.; Harris, N.L. Interactions between commensal intestinal bacteria and the immune system. Nat. Rev. Immunol. 2020, 4, 478-485. [CrossRef]

45. Belkaid, Y.; Hand, T.W. Role of the microbiota in immunity and inflammation. Cell 2014, 157, 121-141. [CrossRef] [PubMed]

46. Geuking, M.B.; Köller, Y.; Rupp, S.; McCoy, K.D. The interplay between the gut microbiota and the immune system. Gut Microbes 2014, 5, 411-418. [CrossRef] [PubMed]

47. Van Praet, J.T.; Donovan, E.; Vanassche, I.; Drennan, M.B.; Windels, F.; Dendooven, A.; Allais, L.; Cuvelier, C.A.; van de Loo, F.; Norris, P.S.; et al. Commensal microbiota influence systemic autoimmune responses. EMBO J. 2015, 34, 466-474. [CrossRef] [PubMed]

48. Sánchez, B.; Hevia, A.; González, S.; Margolles, A. Interaction of Intestinal Microorganisms with the Human Host in the Framework of Autoimmune Diseases. Front. Immunol. 2015, 6, 594. [CrossRef]

49. Ignacio, A.; Morales, C.I.; Câmara, N.O.S.; Almeida, R.R. Innate Sensing of the Gut Microbiota: Modulation of Inflammatory and Autoimmune Diseases. Front. Immunol. 2016, 7, 54. [CrossRef]

50. Human Microbiome Project Consortium. Structure, function and diversity of the healthy human microbiome. Nature 2012, 486, 207-214. [CrossRef]

51. Yatsunenko, T.; Rey, F.E.; Manary, M.J.; Trehan, I.; Dominguez-Bello, M.G.; Contreras, M.; Magris, M.; Hidalgo, G.; Baldassano, R.N.; Anokhin, A.P.; et al. Human gut microbiome viewed across age and geography. Nature 2012, 486, $222-227$. [CrossRef] [PubMed]

52. Wu, G.D.; Chen, J.; Hoffmann, C.; Bittinger, K.; Chen, Y.Y.; Keilbaugh, S.A.; Bewtra, M.; Knights, D.; Walters, W.A.; Knight, R.; et al. Linking long-term dietary patterns with gut microbial enterotypes. Science 2011, 334, 105-108. [CrossRef] [PubMed]

53. Markle, J.G.; Frank, D.N.; Mortin-Toth, S.; Robertson, C.E.; Feazel, L.M.; Rolle-Kampczyk, U.; von Bergen, M.; McCoy, K.D.; Macpherson, A.J.; Danska, J.S. Sex differences in the gut microbiome drive hormone-dependent regulation of autoimmunity. Science 2013, 339, 1084-1088. [CrossRef]

54. Watanabe, A.; Sohail, M.A.; Gomes, D.A.; Hashmi, A.; Nagata, J.; Sutterwala, F.S.; Mahmood, S.; Jhandier, M.N.; Shi, Y.; Flavell, R.A.; et al. Inflammasome-mediated regulation of hepatic stellate cells. Am. J. Physiol. Gastrointest. Liver Physiol. 2009, 296, G1248-G1257. [CrossRef]

55. Strowig, T.; Henao-Mejia, J.; Elinav, E.; Flavell, R. Inflammasomes in health and disease. Nature 2012, 481, 278-286. [CrossRef]

56. Henao-Mejia, J.; Elinav, E.; Jin, C.; Hao, L.; Mehal, W.Z.; Strowig, T.; Thaiss, C.A.; Kau, A.L.; Eisenbarth, S.C.; Jurczak, M.J.; et al. Inflammasome-mediated dysbiosis regulates progression of NAFLD and obesity. Nature 2012, 482, 179-185. [CrossRef]

57. Boaru, S.G.; Borkham-Kamphorst, E.; Tihaa, L.; Haas, U.; Weiskirchen, R. Expression analysis of inflammasomes in experimental models of inflammatory and fibrotic liver disease. J. Inflamm. 2012, 9, 49. [CrossRef]

58. Wu, H.J.; Wu, E. The role of gut microbiota in immune homeostasis and autoimmunity. Gut Microbes 2012, 3, 4-14. [CrossRef] [PubMed]

59. Geuking, M.B.; Cahenzli, J.; Lawson, M.A.; Ng, D.C.; Slack, E.; Hapfelmeier, S.; McCoy, K.D.; Macpherson, A.J. Intestinal bacterial colonization induces mutualistic regulatory T cell responses. Immunity 2011, 34, 794-806. [CrossRef]

60. Hänninen, A.; Salmi, M.; Simell, O.; Jalkanen, S. Mucosa-associated (beta 7-integrinhigh) lymphocytes accumulate early in the pancreas of NOD mice and show aberrant recirculation behavior. Diabetes 1996, 45, 1173-1180. [CrossRef] [PubMed] 
61. Paronen, J.; Klemetti, P.; Kantele, J.M.; Savilahti, E.; Perheentupa, J.; Akerblom, H.K.; Vaarala, O. Glutamate decarboxylase-reactive peripheral blood lymphocytes from patients with IDDM express gut-specific homing receptor alpha4beta7-integrin. Diabetes 1997, 46, 583-588. [CrossRef] [PubMed]

62. Mejía-León, M.E.; Barca, A.M. Diet, Microbiota and Immune System in Type 1 Diabetes Development and Evolution. Nutrients 2015, 7, 9171-9184. [CrossRef]

63. Miyake, S.; Kim, S.; Suda, W.; Oshima, K.; Nakamura, M.; Matsuoka, T.; Chihara, N.; Tomita, A.; Sato, W.; Kim, S.W.; et al. Dysbiosis in the Gut Microbiota of Patients with Multiple Sclerosis, with a Striking Depletion of Species Belonging to Clostridia XIVa and IV Clusters. PLoS ONE 2015, 10, e0137429. [CrossRef] [PubMed]

64. Garrett, W.S.; Gallini, C.A.; Yatsunenko, T.; Michaud, M.; DuBois, A.; Delaney, M.L.; Punit, S.; Karlsson, M.; Bry, L.; Glickman, J.N.; et al. Enterobacteriaceae act in concert with the gut microbiota to induce spontaneous and maternally transmitted colitis. Cell Host Microbe 2010, 8, 292-300. [CrossRef] [PubMed]

65. Elinav, E.; Strowig, T.; Kau, A.L.; Henao-Mejia, J.; Thaiss, C.A.; Booth, C.J.; Peaper, D.R.; Bertin, J.; Eisenbarth, S.C.; Gordon, J.I.; et al. NLRP6 inflammasome regulates colonic microbial ecology and risk for colitis. Cell 2011, 145, 745-757. [CrossRef]

66. Hopf, U.; Möller, B.; Stemerowicz, R.; Lobeck, H.; Rodloff, A.; Freudenberg, M.; Galanos, C.; Huhn, D. Relation between Escherichia coli R(rough)-forms in gut, lipid A in liver, and primary biliary cirrhosis. Lancet 1989, 2, 1419-1422. [CrossRef]

67. Terziroli Beretta-Piccoli, B.; Mazzucchelli, L.; Taiana, C.; Mossi, G.; Usai, C.; Vergani, D.; Mieli-Vergani, G. A patient with primary biliary cholangitis, autoimmune hepatitis, and primary sclerosing cholangitis variant syndrome. J. Transl. Autoimmun. 2019, 3, 100033. [CrossRef]

68. Tabibian, J.H.; O’Hara, S.P.; Trussoni, C.E.; Tietz, P.S.; Splinter, P.L.; Mounajjed, T.; Hagey, L.R.; LaRusso, N.F. Absence of the intestinal microbiota exacerbates hepatobiliary disease in a murine model of primary sclerosing cholangitis. Hepatology 2016, 63, 185-196. [CrossRef]

69. Yuksel, M.; Wang, Y.; Tai, N.; Peng, J.; Guo, J.; Beland, K.; Lapierre, P.; David, C.; Alvarez, F.; Colle, I.; et al. A novel “humanized mouse" model for autoimmune hepatitis and the association of gut microbiota with liver inflammation. Hepatology 2015, 62, 1536-1550. [CrossRef] [PubMed]

70. Lin, R.; Zhou, L.; Zhang, J.; Wang, B. Abnormal intestinal permeability and microbiota in patients with autoimmune hepatitis. Int. J. Clin. Exp. Pathol. 2015, 8, 5153-5160.

71. Elsherbiny, N.M.; Rammadan, M.; Hassan, E.A.; Ali, M.E.; El-Rehim, A.S.A.; Abbas, W.A.; Abozaid, M.A.A.; Hassanin, E.; Hetta, H.F. Autoimmune Hepatitis: Shifts in Gut Microbiota and Metabolic Pathways among Egyptian Patients. Microorganisms 2020, 8, 1011. [CrossRef]

72. Czaja, A.J. Factoring the intestinal microbiome into the pathogenesis of autoimmune hepatitis. World J. Gastroenterol. 2016, 22, 9257-9278. [CrossRef] [PubMed]

73. Abe, K.; Fujita, M.; Hayashi, M.; Okai, K.; Takahashi, A.; Ohira, H. Gut and oral microbiota in autoimmune liver disease. Fukushima J. Med. Sci. 2020, 65, 71-75. [CrossRef]

74. Liwinski, T.; Casar, C.; Ruehlemann, M.C.; Bang, C.; Sebode, M.; Hohenester, S.; Denk, G.; Lieb, W.; Lohse, A.W.; Franke, A.; et al. A disease-specific decline of the relative abundance of Bifidobacterium in patients with autoimmune hepatitis. Aliment. Pharmacol. Ther. 2020, 51, 1417-1428. [CrossRef]

75. Wei, Y.; Li, Y.; Yan, L.; Sun, C.; Miao, Q.; Wang, Q.; Xiao, X.; Lian, M.; Li, B.; Chen, Y.; et al. Alterations of gut microbiome in autoimmune hepatitis. Gut 2020, 69, 569-577. [CrossRef] [PubMed]

76. Honda, M.; Kubes, P. Neutrophils and neutrophil extracellular traps in the liver and gastrointestinal system. Nat. Rev. Gastroenterol. Hepatol. 2018, 15, 206-221. [CrossRef] [PubMed]

77. Ostendorf, L.; Mothes, R.; van Koppen, S.; Lindquist, R.; Bellmann-Strobl, J.; Asseyer, S.; Ruprecht, K.; Alexander, T.; Niesner, R.A.; Hauser, A.E.; et al. Low-Density Granulocytes Are a Novel Immunopathological Feature in Both Multiple Sclerosis and Neuromyelitis Optica Spectrum Disorder. Front. Immunol. 2019, 10, 2725. [CrossRef]

78. Hacbarth, E.; Kajdacsy-Balla, A. Low density neutrophils in patients with systemic lupus erythematosus, rheumatoid arthritis, and acute rheumatic fever. Arthritis Rheum. 1986, 29, 1334-1342. [CrossRef]

79. Wright, H.L.; Makki, F.A.; Moots, R.J.; Edwards, S.W. Low-density granulocytes: Functionally distinct, immature neutrophils in rheumatoid arthritis with altered properties and defective TNF signalling. J. Leukoc. Biol. 2016, 101, 599-611. [CrossRef] [PubMed]

80. Fu, J.; Tobin, M.C.; Thomas, L.L. Neutrophil-like low-density granulocytes are elevated in patients with moderate to severe persistent asthma. Ann. Allergy Asthma Immunol. 2014, 113, 635-640.e2. [CrossRef] [PubMed]

81. Deng, Y.; Ye, J.; Luo, Q.; Huang, Z.; Peng, Y.; Xiong, G.; Guo, Y.; Jiang, H.; Li, J. Low-density granulocytes are elevated in mycobacterial infection and associated with the severity of tuberculosis. PLoS ONE 2016, 11, e0153567. [CrossRef] [PubMed]

82. Lin, A.M.; Rubin, C.J.; Khandpur, R.; Wang, J.Y.; Riblett, M.; Yalavarthi, S.; Villanueva, E.C.; Shah, P.; Kaplan, M.J.; Bruce, A.T. Mast cells and neutrophils release IL-17 through extracellular trap formation in psoriasis. J. Immunol. 2011, 187, 490-500. [CrossRef]

83. Ui Mhaonaigh, A.; Coughlan, A.M.; Dwivedi, A.; Hartnett, J.; Cabral, J.; Moran, B.; Brennan, K.; Doyle, S.L.; Hughes, K.; Lucey, R.; et al. Low Density Granulocytes in ANCA Vasculitis Are Heterogenous and Hypo-Responsive to Anti-Myeloperoxidase Antibodies. Front. Immunol. 2019, 10, 2603. [CrossRef] [PubMed]

84. Porntrakulpipat, S.; Depner, K.R.; Moennig, V. Are low-density granulocytes the major target cells of classical swine fever virus in the peripheral blood? J. Vet. Med. Ser. B 2001, 48, 593-602. [CrossRef] 
85. Hoffmann, M.H.; Bruns, H.; Bäckdahl, L.; Neregård, P.; Niederreiter, B.; Herrmann, M.; Catrina, A.I.; Agerberth, B.; Holmdahl, R. The cathelicidins LL-37 and rCRAMP are associated with pathogenic events of arthritis in humans and rats. Ann. Rheum. Dis. 2013, 72, 1239-1248. [CrossRef] [PubMed]

86. Sagiv, J.Y.; Voels, S.; Granot, Z. Isolation and characterization of low- vs. high-density neutrophils in cancer. Methods Mol. Biol. 2016, 1458, 179-193.

87. Darcy, C.J.; Minigo, G.; Piera, K.A. Neutrophils with myeloid derived suppressor function deplete arginine and constrain T cell function in septic shock patients. Crit. Care 2014, 18, R163. [CrossRef] [PubMed]

88. Cloke, T.; Munder, M.; Taylor, G.; Müller, I.; Kropf, P. Characterization of a novel population of low-density granulocytes associated with disease severity in HIV-1 infection. PLOS ONE 2012, 7, e48939. [CrossRef]

89. Cloke, T.; Munder, M.; Bergin, P.; Herath, S.; Modolell, M.; Taylor, G.; Müller, I.; Kropf, P. Phenotypic alteration of neutrophils in the blood of HIV seropositive patients. PLoS ONE 2013, 8, e72034. [CrossRef] [PubMed]

90. Denny, M.F.; Yalavarthi, S.; Zhao, W.; Thacker, S.G.; Anderson, M.; Sandy, A.R.; McCune, W.J.; Kaplan, M.J. A distinct subset of proinflammatory neutrophils isolated from patients with systemic lupus erythematosus induces vascular damage and synthesizes type I IFNs. J. Immunol. 2010, 184, 3284-3297. [CrossRef]

91. Zhang, S.G.; Song, Y.X.; Shu, X.M.; Shen, H.L.; Yang, H.B.; Duo, R.X.; Wang, G.C. A simple method for removing lowdensity granulocytes to purify $\mathrm{T}$ lymphocytes from peripheral blood mononuclear cells. J. Zhejiang Univ. Sci. B 2017, 18, 605-614. [CrossRef]

92. Villanueva, E.; Yalavarthi, S.; Berthier, C.C.; Hodgin, J.B.; Khandpur, R.; Lin, A.M.; Rubin, C.J.; Zhao, W.; Olsen, S.H.; Klinker, M.; et al. Netting neutrophils induce endothelial damage, infiltrate tissues, and expose immunostimulatory molecules in systemic lupus erythematosus. J. Immunol. 2011, 187, 538-552. [CrossRef]

93. Carmona-Rivera, C.; Zhao, W.; Yalavarthi, S.; Kaplan, M.J. Neutrophil extracellular traps induce endothelial dysfunction in systemic lupus erythematosus through the activation of matrix metalloproteinase-2. Ann. Rheum. Dis. 2015, 74, 1417-1424. [CrossRef] [PubMed]

94. Brinkmann, V.; Reichard, U.; Goosmann, C.; Fauler, B.; Uhlemann, Y.; Weiss, D.S.; Weinrauch, Y.; Zychlinsky, A. Neutrophil Extracellular Traps Kill Bacteria. Science 2004, 303, 1532-1535. [CrossRef] [PubMed]

95. Matoszka, N.; Działo, J.; Tokarz-Deptuła, B.; Deptuła, W. NET and NETosis-New phenomenon in immunology. Postęp. Hig. Med. Dosw. 2012, 66, 437-445. [CrossRef]

96. Papayannopoulos, V.; Zychlinsky, A. NETs: A new strategy for using old weapons. Trends Immunol. 2009, 30, 513-552. [CrossRef]

97. Carmona-Rivera, C.; Kaplan, M.J. Low-density granulocytes: A distinct class of neutrophils in systemic autoimmunity. Semin. Immunopathol. 2013, 35, 455-463. [CrossRef] [PubMed]

98. Kim, T.L.; Kim, H.; Shim, J.S. Neutrophil extracellular traps (NETs) in autoimmune diseases: A comprehensive review. Autoimmun. Rev. 2017, 16, 1160-1173.

99. Mendizabal, M.; Marciano, S.; Videla, M.G.; Anders, M.; Zerega, A.; Balderramo, D.C.; Tisi Baña, M.R.; Barrabino, M.; Gil, O.; Mastai, R.; et al. Fulminant presentation of autoimmune hepatitis: Clinical features and early predictors of corticosteroid treatment failure. Eur. J. Gastroenterol. Hepatol. 2015, 27, 644-648. [CrossRef]

100. Feld, J.J.; Dinh, H.; Arenovich, T.; Marcus, V.A.; Wanless, I.R.; Heathcote, E.J. Autoimmune hepatitis: Effect of symptoms and cirrhosis on natural history and outcome. Hepatology 2005, 42, 53-62. [CrossRef] [PubMed]

101. Teufel, A.; Weinmann, A.; Kahaly, G.J.; Centner, C.; Piendl, A.; Wörns, M.; Lohse, A.W.; Galle, P.R.; Kanzler, S. Concurrent autoimmune diseases in patients with autoimmune hepatitis. J. Clin. Gastroenterol. 2010, 44, 208-213. [CrossRef]

102. Coelho, E.; Matos, A.R.; Caridade, S. Autoimmune Hepatitis and Systemic Sclerosis: A Rare Association. Eur. J. Case Rep. Intern. Med. 2019, 6, 001352. [PubMed]

103. Wei, Q.; Jiang, Y.; Xie, J.; Yang, M.; Zhang, Y.; Wu, Z.; Chen, S.; Liao, Z.; Lin, Z.; Gu, J. Investigation and analysis of HEp 2 indirect immunofluorescence titers and patterns in various liver diseases. Clin. Rheumatol. 2020, 39, 2425-2432. [CrossRef] [PubMed]

104. Galaski, J.; Weiler-Normann, C.; Schakat, M.; Zachou, K.; Muratori, P.; Lampalzer, S.; Haag, F.; Schramm, C.; Lenzi, M.; Dalekos, G.N.; et al. Update of the simplified criteria for autoimmune hepatitis: Evaluation of the methodology for immunoserological testing. J. Hepatol. 2020, 74, 310-320. [CrossRef]

105. Invernizzi, P.; Alessio, M.G.; Smyk, D.S.; Lleo, A.; Sonzogni, A.; Fabris, L.; Candusso, M.; Bogdanos, D.P.; Iorio, R.; Torre, G. Autoimmune hepatitis type 2 associated with an unexpected and transient presence of primary biliary cirrhosis-specific antimitochondrial antibodies: A case study and review of the literature. BMC Gastroenterol. 2012, 12, 92. [CrossRef] [PubMed]

106. Johnson, P.J.; McFarlane, I.G. Convenors, On Behalf of the Panel Meeting report: International Autoimmune Hepatitis Group. Hepatology 1993, 18, 998-1005. [CrossRef]

107. Alvarez, F.; Berg, P.A.; Bianchi, F.B.; Bianchi, L.; Burroughs, A.K.; Cancado, E.L.; Chapman, R.W.; Cooksley, W.G.; Czaja, A.J.; Desmet, V.J.; et al. International Autoimmune Hepatitis Group Report: Review of criteria for diagnosis of autoimmune hepatitis. J. Hepatol. 1999, 31, 929-938. [CrossRef]

108. Yeoman, A.D.; Westbrook, R.H.; Al-Chalabi, T.; Carey, I.; Heaton, N.D.; Portmann, B.C.; Heneghan, M.A. Diagnostic value and utility of the simplified International Autoimmune Hepatitis Group (IAIHG) criteria in acute and chronic liver disease. Hepatology 2009, 50, 538-545. [CrossRef]

109. Wong, R.J.; Gish, R.; Frederick, T.; Bzowej, N.; Frenette, C. The impact of race/ethnicity on the clinical epidemiology of autoimmune hepatitis. J. Clin. Gastroenterol. 2012, 46, 155-161. [CrossRef] [PubMed] 
110. Vergani, D.; Alvarez, F.; Bianchi, F.B.; Cançado, E.L.; Mackay, I.R.; Manns, M.P.; Nishioka, M.; Penner, E. Liver autoimmune serology: A consensus statement from the committee for autoimmune serology of the International Autoimmune Hepatitis Group. J. Hepatol. 2004, 41, 677-683. [CrossRef]

111. Zachou, K.; Muratori, P.; Koukoulis, G.K.; Granito, A.; Gatselis, N.; Fabbri, A.; Dalekos, G.N.; Muratori, L. Review article: Autoimmune hepatitis-Current management and challenges. Aliment. Pharmacol. Ther. 2013, 38, 887-913. [CrossRef]

112. Muratori, P.; Fabbri, A.; Lalanne, C.; Lenzi, M.; Muratori, L. Autoimmune liver disease and concomitant extrahepatic autoimmune disease. Eur. J. Gastroenterol. Hepatol. 2015, 27, 1175-1179. [CrossRef]

113. Mack, C.L.; Adams, D.; Assis, D.N.; Kerkar, N.; Manns, M.P.; Mayo, M.J.; Vierling, J.M.; Alsawas, M.; Murad, M.H.; Czaja, A.J. Diagnosis and management of autoimmune hepatitis in adults and children: 2019 practice guidance and guidelines from the American Association for the Study of Liver Diseases. Hepatology 2020, 72, 671-722. [CrossRef] [PubMed]

114. European Association for the Study of the Liver. EASL clinical practice guidelines: Autoimmune hepatitis. J. Hepatol. 2015, 63, 971-1004. [CrossRef]

115. Gatselis, N.K.; Zachou, K.; Koukoulis, G.K.; Dalekos, G.N. Autoimmune hepatitis, one disease with many faces: Etiopathogenetic, clinico-laboratory and histological characteristics. World J. Gastroenterol. 2015, 21, 60-83. [CrossRef] [PubMed]

116. Wu, S.; Yang, Z.; Zhou, J.; Zeng, N.; He, Z.; Zhan, S.; Jia, J.; You, H. Systematic review: Diagnostic accuracy of non-invasive tests for staging liver fibrosis in autoimmune hepatitis. Hepatol. Int. 2019, 13, 91-101. [CrossRef]

117. Stirnimann, G.; Ebadi, M.; Czaja, A.J.; Montano-Loza, A.J. Recurrent and de novo autoimmune hepatitis. Liver Transpl. 2019, 25, 152-166. [CrossRef]

118. Hanouneh, M.; Ritchie, M.M.; Ascha, M.; Ascha, M.S.; Chedid, A.; Sanguankeo, A.; Zein, N.N.; Hanouneh, I.A. A review of the utility of tacrolimus in the management of adults with autoimmune hepatitis. Scand. J. Gastroenterol. 2019, 54, 76-80. [CrossRef]

119. Schmeltzer, P.A.; Russo, M.W. Clinical narrative: Autoimmune hepatitis. Am. J. Gastroenterol. 2018, 113, 951-958. [CrossRef]

120. Liwinski, T.; Schramm, C. Autoimmune hepatitis-Update on clinical management in 2017. Clin. Res. Hepatol. Gastroenterol. 2017, 41, 617-625. [CrossRef]

121. Harada, K.; Hiep, N.C.; Ohira, H. Challenges and difficulties in pathological diagnosis of autoimmune hepatitis. Hepatol. Res. 2017, 47, 963-971. [CrossRef] [PubMed]

122. Tiniakos, D.G.; Brain, J.G.; Bury, Y.A. Role of histopathology in autoimmune hepatitis. Dig. Dis. 2015, 33, 53-64. [CrossRef]

123. Moriyama, T.; Nishii, R.; Perez-Andreu, V.; Yang, W.; Klussmann, F.A.; Zhao, X.; Lin, T.N.; Hoshitsuki, K.; Nersting, J.; Kihira, K.; et al. NUDT15 polymorphisms alter thiopurine metabolism and hematopoietic toxicity. Nat. Genet. 2016, 48, 367-373. [CrossRef] [PubMed]

124. Pape, S.; Gevers, T.J.G.; Belias, M.; Mustafajev, I.F.; Vrolijk, J.M.; van Hoek, B.; Bouma, G.; van Nieuwkerk, C.M.J.; Hartl, J.; Schramm, C.; et al. Predniso(lo)ne dosage and chance of remission in patients with autoimmune hepatitis. Clin. Gastroenterol. Hepatol. 2019, 17, 2068-2075.e2. [CrossRef] [PubMed]

125. Vierling, J.M.; Kerkar, N.; Czaja, A.J.; Mack, C.L.; Adams, D.; Assis, D.N.; Manns, M.P.; Mayo, M.J.; Nayfeh, T.; Majzoub, A.M.M.; et al. Immunosuppressive treatment regimens in autoimmune hepatitis: Systematic reviews and meta-analyses supporting American Association for the Study of Liver Diseases guidelines. Hepatology 2020, 72, 753-769. [CrossRef] [PubMed]

126. American Gastroenterological Association. American Gastroenterological Association medical position statement: Osteoporosis in hepatic disorders. Gastroenterology 2003, 125, 937-940. [CrossRef]

127. De Lemos-Bonotto, M.; Valle-Tovo, C.; Costabeber, A.M.; Mattos, A.A.; Azeredo-da-Silva, A.L.F. A systematic review and meta-analysis of second-line immunosuppressants for autoimmune hepatitis treatment. Eur. J. Gastroenterol. Hepatol. 2018, 30, 212-216. [CrossRef]

128. Nicoll, A.J.; Roberts, S.K.; Lim, R.; Mitchell, J.; Weltman, M.; George, J.; Wigg, A.; Stuart, K.; Gow, P.; MacQuillan, G.; et al. Beneficial response to mycophenolate mofetil by patients with autoimmune hepatitis who have failed standard therapy, is predicted by older age and lower immunoglobulin G and INR levels. Aliment. Pharmacol. Ther. 2019, 49, 1314-1322. [CrossRef]

129. Yoshizawa, K.; Matsumoto, A.; Ichijo, T.; Umemura, T.; Joshita, S.; Komatsu, M.; Tanaka, N.; Tanaka, E.; Ota, M.; Katsuyama, Y.; et al. Long-term outcome of Japanese patients with type 1 autoimmune hepatitis. Hepatology 2012, 56, 668-676. [CrossRef]

130. Heinemann, M.; Adam, R.; Berenguer, M.; Mirza, D.; Malek-Hosseini, S.A.; O’Grady, J.G.; Lodge, P.; Pratschke, J.; Boudjema, K.; Paul, A.; et al. Longterm survival after liver transplantation for autoimmune hepatitis: Results from the European Liver Transplant Registry. Liver Transpl. 2020, 26, 866-877. [CrossRef]

131. Wang, H.; Feng, X.; Yan, W.; Tian, D. Regulatory T Cells in Autoimmune Hepatitis: Unveiling Their Roles in Mouse Models and Patients. Front. Immunol. 2020, 11, 575572. [CrossRef]

132. Halliday, N.; Dyson, J.K.; Thorburn, D.; Lohse, A.W.; Heneghan, M.A. Review article: Experimental therapies in autoimmune hepatitis. Aliment. Pharmacol. Ther. 2020, 52, 1134-1149. [CrossRef] [PubMed] 